DOI: $10.1590 / 1089-6891 v 17 i 434091$

VETERINARY MEDICINE

\title{
SEROPREVALENCE OF Trypanosoma vivax, Anaplasma marginale, and Babesia bovis IN DAIRY CATTLE
}

\section{SOROPREVALENCIA DE Trypanosoma vivax, Anaplasma marginale e Babesia bovis EM REBANHOS LEITEIROS}

\author{
Jonata de Melo Barbieri ${ }^{1}$ \\ Yuly Andrea Caicedo Blanco ${ }^{1}$ \\ Fábio Raphael Pascoti Bruhn² \\ Antônio Marcos Guimarães ${ }^{1 *}$ \\ ${ }^{1}$ Universidade Federal de Minas Gerais, Belo Horizonte, Minas Gerais, Brasil. \\ Universidade Federal de Pelotas, Pelotas, Rio Grande do Sul, Brasil. \\ *Autor para correspondência - amg@dmv.ufla.br
}

\begin{abstract}
In order to determine the prevalence of IgG against Trypanosoma vivax, Anaplasma marginale, and Babesia bovis in dairy cattle in southern Minas Gerais, four hundred cows from 40 dairy farms were randomly selected and distributed in 14 municipalities. Seroprevalence was determined by indirect immunofluorescence assay (IFA). Interviews were conducted to characterize producers and dairy production. Univariate analysis was carried out using chi-square $\left(\mathrm{x}^{2}\right)$ or Fisher's exact test. The multiple model was constructed with variables associated with $\mathrm{p} \leq 0.25$ by $\mathrm{x}^{2}$ test using generalized estimating equations (GEE). True prevalence at herd level was 49.6\% (31.7-67.5), 100\% (92.1-100), and $100 \%$ (86.5-100) for T. vivax, A. marginale, and B. bovis, respectively. At individual level, true seroprevalence was 9.9\% (6.7-13.1), 96.2\% (92.1-99.6), and 93.7\% (89.4-97.2), respectively, for T. vivax, A. marginale, and B. bovis. Among the factors adjusted by logistic regression GEE model, "total farm area" $\left(\mathrm{p}=0.021, \mathrm{OR}=0.308, \mathrm{Ic}_{95 \%}=0.114-0.836\right)$ and "fly season" $(\mathrm{p}=0.016, \mathrm{OR}=2.133$, $\left.\mathrm{Ic}_{95 \%}=1.153-3.948\right)$ remained associated with seropositivity for T. vivax. As the State of Minas Gerais is considered non-endemic for T. vivax, producers and veterinarians should be informed about the risk of occurrence of bovine trypanosomiasis.
\end{abstract}

Keywords: anaplasmosis; babesiosis; dairy cattle; enzootic stability; trypanosomiasis.

\section{Resumo}

Com o objetivo de determinar a prevalência de anticorpos IgG anti-Trypanosoma vivax, Anaplasma marginale e Babesia bovis em bovinos leiteiros no Sul de Minas Gerais, quatrocentas fêmeas bovinas adultas provenientes de 40 propriedades leiteiras foram selecionadas aleatoriamente e distribuídas por 14 municípios localizados na região Sul de Minas Gerais. A soroprevalência foi determinada pela reação de imunofluorescência indireta (RIFI). Foram realizadas entrevistas para caracterizar os produtores e a produção leiteira. As análises estatísticas foram realizadas no software PASW 18. Foi realizada análise univariada pelo Qui-quadrado $\left(\mathrm{x}^{2}\right)$ ou Teste Exato de Fisher. Com as variáveis associadas com $\mathrm{p} \leq 0,25$ pelo teste $\mathrm{x}^{2}$ construiu-se o modelo múltiplo por meio de Equações de Estimação Generalizadas (GEE). A soroprevalência verdadeira em nível de rebanho foi 49,6\% (31,7$67,5), 100 \%(92,1-100)$ e $100 \%(86,5-100)$ para $T$. vivax, A. marginale e B. bovis, respectivamente. Em nível individual, a soroprevalência verdadeira foi 9,9\% (6,7-13,1), 96,2\% (92,1-99,6) e 93,7\% (89,4-97,2), respectivamente, para T. vivax, A. marginale e B. bovis. Dentre os fatores ajustados 
pelo modelo de regressão logística GEE, as variáveis "área total da fazenda" $(\mathrm{p}=0,021 ; \mathrm{OR}=0,308$; IC95\% $=0,114-0,836)$ e "época com maior número de moscas" $(\mathrm{p}=0,016 ; \mathrm{OR}=2,133 ; \mathrm{IC} 95 \%=$ $1,153-3,948)$ se mantiveram associadas à soropositividade para $T$. vivax. Devido ao fato de o Estado de Minas Gerais ser considerado área não endêmica para a $T$. vivax, é importante que produtores e veterinários sejam informados quanto ao risco de ocorrência da tripanossomíase bovina.

Palavras-chave: anaplasmose; babesiose; bovinos leiteiros; estabilidade enzoótica; tripanossomíase.

Enviado em: 23 fevereiro de 2015

Aceito em: 17 agosto de 2016

\section{Introduction}

Trypanosoma vivax (Kinetoplastida: Trypanosomatidae) causes bovine trypanosomiasis, a parasitic disease of great economic importance in Africa, whose biological vector is the tsetse fly. However, outside the African continent T. vivax underwent adaptation to mechanical transmission by bloodsucking flies such as horseflies (tabanids) and Stomoxys calcitrans, allowing for territorial expansion of bovine trypanosomiasis to several countries in Central America, South America, and the Caribbean ${ }^{(1)}$. Other transmission method is iatrogenesis via needles and instruments during vaccinations and mass treatments ${ }^{(2,3)}$.

In Brazil, bovine trypanosomiasis caused by T. vivax was first reported in 1972 in buffaloes in the northern state of Pará( ${ }^{(4)}$. For about two decades, this parasite was restricted to the North region, also occurring in the state of Amapá ${ }^{(5)}$. However, further outbreaks of bovine trypanosomiasis caused by T. vivax were confirmed in the North ${ }^{(6)}$, Northeast ${ }^{(7,8)}$, Midwest ${ }^{(9,10)}$, Southeast ${ }^{(11,12)}$, and South ${ }^{(13)}$.

In endemic areas such as the Pantanal and North region, $T$. vivax rarely causes a clinical disease in cattle. However, when cattle infected with T. vivax from endemic areas are introduced in parasite-free areas, the agent can spread and cause outbreaks of trypanosomiasis in cattle, with severe clinical signs of disease and eventually death ${ }^{(7,14)}$. Severe anemia was the main sign of disease ${ }^{(15)}$ in the first outbreak of trypanosomiasis caused by T. vivax in Minas Gerais, reported on a dairy farm in Igarapé( ${ }^{(11)}$. An outbreak of T. vivax in cattle was also reported in Uberaba, in Minas Gerais in 2012, with 50\% of positivity in 16 animals sampled during the outbreak. Added to this report, a serological study was developed in Uberaba, revealing a prevalence of $T$. vivax around $16.2 \%$ in 327 animals sampled ${ }^{(16)}$.

In Brazil, Babesia bovis and B. bigemina (Piroplasmorida: Babesiidae) protozoa are the etiological agents of bovine babesiosis, while anaplasmosis is caused by obligate intraerythrocytic bacteria Anaplasma marginale (Rickettsiales: Anaplasmataceae). The Rhipicephalus (Boophilus) microplus (Acari: Ixodidae) tick is the main vector of these blood parasites that cause anemia in cattle from South and Central America ${ }^{(17)}$, which are responsible for significant economic losses in dairy cattle in tropical and subtropical areas in the world ${ }^{(18)}$.

Brazil is considered enzootic for B. bovis and $A$. marginale, with herd infection rates of $80-100 \%$ in several regions ${ }^{(19)}$. Enzootic instability situations are not common in the country and are usually associated with climatic factors causing seasonal variations in the population dynamics of vector tick R. (B.) microplus ${ }^{(20)}$.

The state of Minas Gerais is a major hub of agricultural production and dairy farming in Brazil, accounting for approximately $25 \%$ (13,636 million head) of cows milked and $28 \%(20,156$ billion liters) of total milk production in the country in $2010^{(21)}$. Southern Minas Gerais stands as a major dairy region, supplying big cities like São Paulo and providing raw material for the state's own dairy industries.

This study determined the prevalence of IgG antibodies against $T$. vivax, A. marginale, and B. bovis in dairy cattle in southern Minas Gerais. The state is considered non-endemic for bovine trypanosomiasis, 
with a single report of disease occurrence so far. Considering the prominent role of the state in milk production nationwide and total lack of research on the prevalence of T. vivax in dairy cattle in the region, this study is epidemiologically relevant to monitor the serological status of the hemoprotozoan parasite in the region. The study is also clinically important to help veterinarians in differential diagnosis of cattle suffering from acute hemolytic syndrome, since bovine trypanosomiasis clinical signs are similar to those of bovine babesiosis and anaplasmosis.

\section{Material and Methods}

This observational cross-section study was conducted to evaluate the prevalence of IgG antibodies against $T$. vivax, A. marginale, and B. bovis in 400 apparently normal cows from 40 dairy farms, randomly selected and distributed in 14 municipalities in Southern Minas Gerais (45 W meridian, 21 S parallel) (Figure 1).

To calculate herd true prevalence, sensitivity and specificity tests were adjusted from individual level to herd level using Herdacc software ${ }^{(22)}$. A herd was deemed positive if at least one animal was tested positive. To calculate true prevalence of specific IgG antibodies against $T$. vivax we used values of sensitivity (85.7\%), according to Ashkar and Ochilo ${ }^{(23)}$, and specificity (100\%) according to Platt and Adams ${ }^{(24)}$. Values of sensitivity $(92 \%)$ and specificity $(95 \%)$ for B. bovis were used according to Ogunremi et al. ${ }^{(25)}$, and sensitivity $(90.7 \%)$ and specificity $(100 \%)$ for $A$. marginale according to Ekici and Sevinc ${ }^{(26)}$. Subsequently, sensitivity and specificity values among herds were used to calculate true prevalence at herd level ${ }^{(27)}$, using Epitools epidemiological calculators ${ }^{(28)}$. The confidence intervals for true prevalence were calculated according to Reiczigel et al. ${ }^{(29)}$.

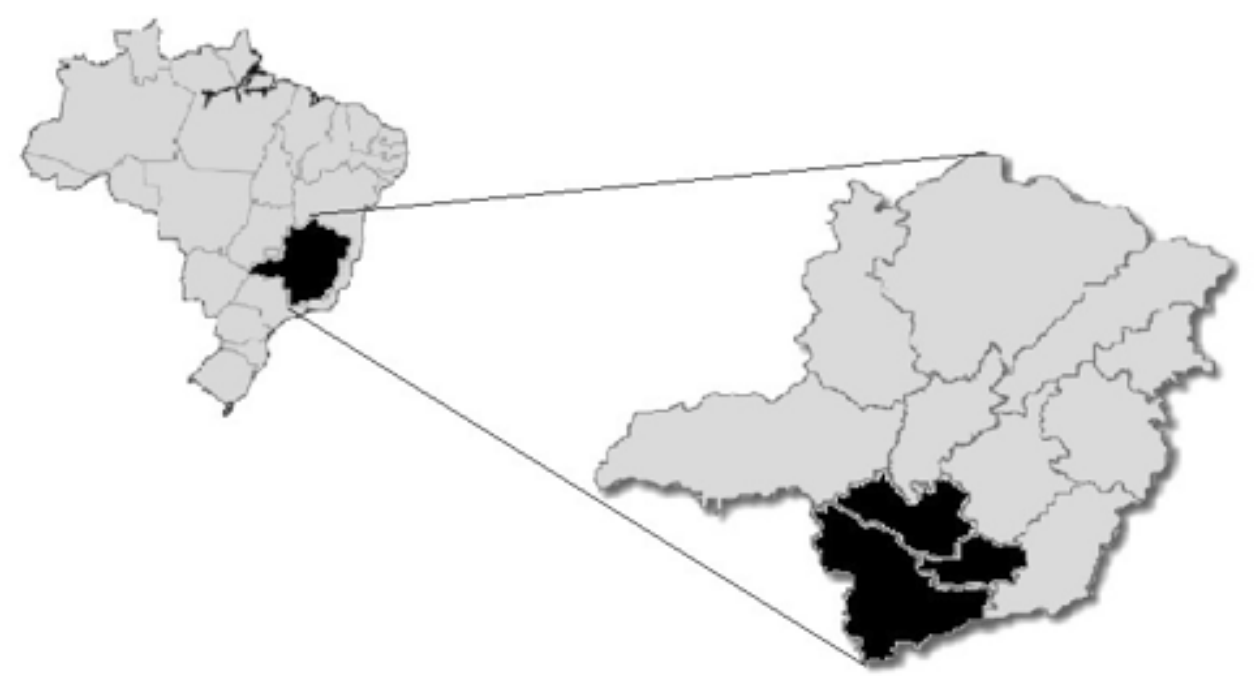

Figure 1. Map highlighting the three sampling areas (dark) in Southern Minas Gerais, Brazil. 
Serum samples were drawn (10 sera per herd) from 1200 samples (30 sera per herd) used in a previous study that determined prevalence of IgG antibodies against Neospora caninum in dairy cattle in the sampling areas shown in Figure $1^{(30)}$. The number of animals $(\mathrm{n})$ needed to estimate prevalence was based on the Pan American Zoonoses Center ${ }^{(31)}$ formula: $n=\left[p \times(100-p) \times Z^{2}\right] /(d \times p / 100)^{2}$. Considering an estimated prevalence (p) of 50\%, confidence level (z) at $95 \%$ of 1.96 and allowable margin of error (d) 10\%, we obtained a minimum number (n) of 384 serum samples. Upon visiting the farms we conducted pre-tested semi-structured interviews to collect information (independent variables) on possible factors associated with occurrence of T. vivax and to characterize farmers and milk production. This interview form was approved by the Ethics Committee in the Use of Animals/ CEUA from Universidade Federal de Lavras under the protocol 082/2011. Information about herds is shown in Table 1.

Table 1. Dichotomized categories of each independent variable in statistical analysis associated with seropositivity for Trypanosoma vivax in dairy herds in Southern Minas Gerais, Brazil

\begin{tabular}{lccc}
\hline $\mathbf{N}^{\circ}$ & Characteristics & Code $\mathbf{0}$ & Code $\mathbf{l}$ \\
\hline 1 & Total farm area * & $\leq 110$ ha & $>110$ ha \\
2 & Wetlands & Yes & No \\
3 & Production of type A milk & Yes & No \\
4 & Production of type B milk & Yes & No \\
5 & Production of type C milk & Yes & No \\
6 & Activity type & Milk production & Mixed farming \\
7 & Abortion occurrence & Yes & No \\
8 & Bordering dairy farms & Yes & No \\
9 & Veterinary care & Yes & No \\
10 & Purchase of breeding cattle & Yes & No \\
11 & Purchase of cattle from São Paulo & Yes & No \\
12 & Purchase of cattle from Mato Grosso do Sul & Yes & No \\
13 & Rented pasture & Yes & No \\
14 & Shared pasture & Yes & No \\
15 & Forestland & Yes & No \\
16 & Livestock access to forestland & Yes & No \\
17 & Frequency of reproductive problems * & $\leq 20 \%$ & $>20 \%$ \\
18 & Occurrence of rabies & Yes & No \\
19 & Fly season* & Rainfall & All year round \\
20 & Fly frequency* & Never, rarely, low & Medium, high \\
21 & Frequency of horse flies (tabanids)* & & Medium, high \\
\hline
\end{tabular}

In this study, farms had a total median area of 110 hectares (interquartile range $(I R)=223$ ) with exclusive area for milk production (corral, milking parlor, and pasture) of 20 ha $(\mathrm{IR}=68)$. The median number of dairy cows was 82 (lactation + dry period) $(\mathrm{Q} 1=50.5 ; \mathrm{Q} 3=148.75)$ and 62 lactating cows $(\mathrm{Q} 1=40 ; \mathrm{Q} 3=120)$. Average milk yield was $20 \pm 7.4$ liters per cow and 1,350 liters per day $(\mathrm{Q} 1=$ $562.5, \mathrm{Q} 3=2,287.5)$, indicating a high production well above the average of dairy farms in Brazil (41 liters/day) and particularly in the State of Minas Gerais (69 liters/day) ${ }^{(32)}$.

Seroprevalence was determined by indirect immunofluorescence assay (IFA) according to the 
technique described by the Inter-American Institute on Cooperation for Agriculture ${ }^{(33)}$. Antigens were trypomastigotes of $T$. vivax from splenectomized goats experimentally infected with strain Igarapé/ $\mathrm{MG}^{(15)}$ and antigens of $A$. marginale and $B$. bovis prepared as described by Carvalho et al. ${ }^{(34)}$. After being thawed at room temperature, the sera were tested for $T$. vivax without PBS dilution. Then, the sera considered reagent for IgG against $T$. vivax were retested and deemed positive if showing reaction at dilution 1:80(15). Sera were considered positive for $B$. bovis and A. marginale if reacted at dilution 1:320(34). In the preparation of slides for IFA we used serum test for each agent, positive and negative controls, and conjugated anti-bovine IgG (Sigma, St. Louis, MO, USA) diluted 1:100.

Statistical analyzes were performed using PASW 18 software. Before applying statistical tests, almost all questionnaire questions were classified, dichotomized, and evaluated based on response frequency. For example, single response variables were excluded.

Factors associated with seropositivity for $T$. vivax were identified by statistical analysis, considering IFA serological results as a dependent variable and questionnaire data as independent variables. Thus, the association between dependent and independent variables was initially assessed by chi-square univariate analysis $\left(\mathrm{x}^{2}\right)$ or Fisher's exact test (less than five observations in at least one cell in the contingency table). Odds ratio (OR) was calculated for the statistically related variables $(\mathrm{p}<0.05)$ at confidence interval of $95 \%$. The variables subjected to $\mathrm{x}^{2}$ test were evaluated for collinearity to construct the multiple model. When variables correlated (coefficients $>0.8$ ), the variable more likely to be related to seropositivity for T. vivax was maintained. When $\mathrm{p} \leq 0.25$ by $\mathrm{x}^{2}$ test, the variables were selected to construct the multiple model ${ }^{(35)}$.

Association between significant variables at herd level and seroprevalence were assessed using generalized estimating equations (GEE). This model is more appropriate when the associated data are found in different dimensions, such as in this study assessing cows from different farms ${ }^{(36)}$. Each farm was considered a subject and each animal a case, assuming a relationship of dependency between cows raised on the same farm and independence between animals raised in different properties. The risk for all variables associated on the final multiple model $(p<0.05)$ was estimated using the adjusted OR at confidence interval 95\%.

\section{Results}

In most farms, dairy farming is the only source of income $(55.0 \%)$ while others produce refrigerated raw milk (52.5\%) and raise crossbred cattle (51.3\%). Furthermore, most farmers have been producing milk on the same farms for over 20 years $(51.3 \%)$, and $65.0 \%$ of dairy cattle workers have only minimal education ( $4^{\text {th }}$ grade elementary school). Nevertheless, in most farms $(60.0 \%)$ cows were raised in a semi-intensive system and milked twice a day $(87.5 \%)$ by automatic milking systems (72.5\%). Artificial insemination $(65.0 \%)$ was the main reproductive method.

True prevalence at herd level for T. vivax, A. marginale, and B. bovis was 49.6\% (31.7-67.5), 100\% (92.1-100), and 100\% (86.5-100), respectively. At individual level, values were 9.9\% (6.7-13.1), 96.2\% (92.1-99.6), and 93.7\% (89.4-97.2) for T. vivax, A. marginale, and B. bovis, respectively. Factors associated with seropositivity for $A$. marginale and $B$. bovis were not analyzed in this study because of the high true seroprevalence found for these hemoparasites at both herd and individual levels.

Eight variables were used in the multivariate analysis (Table 2), which considered data of 400 cattle from 40 herds. We found a significant association $(\mathrm{p}<0.05)$ with seropositivity for $T$. vivax in the univariate analysis $\left(\mathrm{x}^{2}\right)$ for some factors related to farm structure and management, such as total farm area, occurrence of horse flies (tabanids), and flies. However, after adjustment by logistic regression GEE model, only the variables 'total farm area' $(\leq 110$ ha and $>110 \mathrm{ha})\left(\mathrm{p}=0.021, \mathrm{OR}=0.308, \mathrm{Ic}_{95 \%}=\right.$ $0.114-0.836$ ) and 'fly season' (all year round) $\left(\mathrm{p}=0.016, \mathrm{OR}=2.133, \mathrm{Ic}_{95 \%}=1.153-3.948\right.$ ) remained significantly associated $(\mathrm{p}<0.05)$ with serum positivity for $T$. vivax. 
Table 2. Variables with $\mathrm{p} \leq 0.25$ by chi-square test used in the construction of Generalized Estimating Equations (GEE)

\begin{tabular}{|c|c|c|c|c|}
\hline \multirow[b]{2}{*}{ Characteristics } & \multicolumn{2}{|c|}{ Frequency } & \multirow[b]{2}{*}{ Missing } & \multirow[b]{2}{*}{ Total } \\
\hline & 0 & 1 & & \\
\hline \multicolumn{5}{|l|}{ Total area } \\
\hline$\leq 110$ ha $(0),>110$ ha $(1)$ & 20 & 19 & 1 & 40 \\
\hline \multicolumn{5}{|l|}{ Frequency of reproductive problems } \\
\hline$\leq 20 \%(0),>20 \%(1)$ & 28 & 11 & 1 & 40 \\
\hline \multicolumn{5}{|l|}{ Fly season } \\
\hline Rainfall (0), all year round (1) & 38 & 2 & 0 & 40 \\
\hline \multicolumn{5}{|l|}{ Type B milk } \\
\hline No (0), Yes (1) & 24 & 16 & 0 & 40 \\
\hline \multicolumn{5}{|l|}{ Occurrence of horse flies (tabanids) } \\
\hline Never, rarely, low (0), Medium, high (1) & 32 & 8 & 0 & 40 \\
\hline \multicolumn{5}{|l|}{ Type C milk } \\
\hline No (0), Yes (1) & 18 & 22 & 0 & 40 \\
\hline \multicolumn{5}{|l|}{ Type of purchase } \\
\hline Calves and Heifers (0), Cows (1) & 7 & 5 & 28 & 40 \\
\hline \multicolumn{5}{|l|}{ Occurrence of flies } \\
\hline Never, rarely, low (0), Medium, high (1) & 9 & 31 & 0 & 40 \\
\hline
\end{tabular}

\section{Discussion}

Most of the Brazilian cattle farms are established in areas of enzootic stability for $A$. marginale and $B$. bovis, with seroprevalence rates of $80-100 \%$ in dairy farms ${ }^{(19)}$. In areas of enzootic stability there is a balance between immunity and disease, where $75 \%$ or more of cattle over nine months old are seropositive for hemoparasites ${ }^{(37)}$. In this study, true prevalence rates at farm level and animal level to A. marginale and B. bovis were higher than $75 \%$, with a confidence interval reaching $100 \%$. This result is consistent with those reported in other studies conducted in Brazil ${ }^{(19)}$, and particularly in dairy cattle in Southern Minas Gerais ${ }^{(38)}$, which is characterized as enzootic stable for $A$. marginale and $B$. bovis with low risk of anaplasmosis or acute babesiosis in native adult animals.

True prevalence rate of T. vivax at individual level was $9.9 \%$, similar to the rate found in the first and only outbreak of trypanosomiasis by $T$. vivax reported in Minas Gerais so far (7.4\%) on a dairy farm in Igarapé, metropolitan mesoregion of Belo Horizonte ${ }^{(15)}$, and below the rate found in Pernambuco, $14 \%{ }^{(8)}$. However, prevalence rates of $30.7-93.1 \%$ are not uncommon in Brazilian endemic areas such as Pantanal and North Region ${ }^{(9,39,40)}$, well above those reported in Southern Minas Gerais.

We found a significant association $(\mathrm{p}<0.05)$ between fly season and seroprevalence for $T$. vivax in dairy cattle. Occurrence of high amount of flies throughout the year increases probability of seropositivity for $T$. vivax compared to farms where a fly season occurs. According to Batista et al. ${ }^{(41)}$, chronically infected animals and mechanical vectors (S. calcitrans and Tabanus spp.) contribute to the spread of T. vivax infection in cattle herds.

There was also a significant association $(\mathrm{p}<0.05)$ between total farm area and seroprevalence for $T$. vivax. Farms larger than 110 hectares have lower chance of occurrence, probably due to a higher level of technology, appropriate health management, and constant veterinary care.

The results indicate that Southern Minas Gerais is an area of enzootic stability for $A$. marginale and 
B. bovis, with low risk of blood parasite disease in adult native cattle. In this region, dairy cattle are exposed to T. vivax. No higher seroprevalence for T. vivax was found in cattle raised on farms that had purchased animals from areas of occurrence of T. vivax, such as the states of São Paulo, Mato Grosso, and Mato Grosso do Sul. However, according to Cadioli et al. ${ }^{(12)}$, the source of contamination in the first outbreak of T. vivax in São Paulo was cattle from infected farms in Mato Grosso do Sul. Within six months, $100 \%$ of cows seroconverted on the farm where infected animals had been introduced.

Thus, probably the occurrence of dairy cattle infected with $T$. vivax in Southern Minas Gerais is due to the introduction of chronically infected animals from endemic regions in areas considered free of $T$. vivax, with blood-sucking flies (tabanids and $S$. calcitrans) acting as mechanical vectors. This argument is supported by studies conducted in Brazil, which first reported the occurrence of outbreaks of trypanosomiasis in areas considered free of $T$. vivax ${ }^{(11,12,15)}$. Also, goats can be asymptomatic reservoirs and an important source of T. vivax for cattle ${ }^{(42)}$.

The high prevalence of $T$. vivax among dairy herds in Southern Minas Gerais indicates the need for health care to prevent spread to regions considered free of the parasite, within or outside the state. As cattle maintain a chronic silent infection, farmers should be advised to verify the origin of the livestock they purchase. Moreover, as acute bovine trypanosomiasis caused by T. vivax is severe, veterinarians should be prepared to undertake the diagnosis and early treatment. According to Batista et al. ${ }^{(14)}$, however, proper diagnosis is complicated by similarity between clinical signs of trypanosomiasis and other diseases, added to the lack of knowledge of $T$. vivax infection. Diseases such as anaplasmosis and babesiosis, which have similar clinical signs to bovine trypanosomiasis (fever, anemia, and lethargy, loss of appetite, reduced production, and abortion), can hinder an accurate diagnosis ${ }^{(14,15,42)}$. Thus, veterinarians should be informed of the risk of bovine trypanosomiasis caused by T. vivax and clinical suspicion in Southern Minas Gerais, especially in cases of adult cattle with acute hemolytic syndrome and severe anemia.

\section{Acknowledgments}

To the Foundation for Research Support of the State of Minas Gerais (FAPEMIG) for financial support (CBB APQ-00855/13). To Dr. Múcio Flávio Barbosa Ribeiro (Federal University of Minas Gerais - UFMG) for providing antigen slides and Dr. Jael Batista Soares (Federal Rural University of the Semi-Arid Region - UFERSA) for providing the sera used as positive and negative controls for serology testing.

Conflict of interest: The authors declare that they have no conflict of interest.

\section{References}

1 - Silva RAMS, Seidl A, Ramirez L, Dávila AMR. Trypanosoma evansi e Trypanosoma vivax - Biologia, Diagnóstico e Controle, EMBRAPA (Empresa Brasileira de Pesquisa Agropecuária), 2002, Corumbá, Brasil,

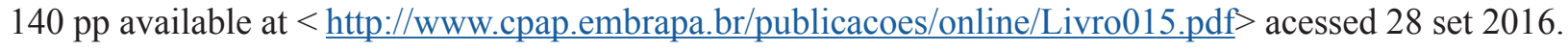

2 - Jones, TW, Dávila, AMR. Trypanosoma vivax - out of Africa. Trends Parasitology, 2001;12:99-101.

3 - Agudo, L, Tamasaukas, R, Silva, A, Sanchéz, J, Ron, J, Fernandez, M, Florio, J, Vintimilla, M, Colmenarez, O, Riviera, S. Tipo bovino trypanotolerante y trypanosusceptible doble propósito en la región de los Llanos Centrales de Venezuela. I: Identificación y caracterización fenotípica. REDVET. Revista Electrónica de Veterinária, 2009;10:1-23.

4 - Shaw JJ, Lainson R. Trypanosoma vivax in Brazil. Annals of Tropical Medicine and Parasitology, 
$1972 ; 66: 25-32$.

5 - Serra-freire NM. Oiapoque-outro foco de Trypanosoma vivax no Brasil. Revista Brasileira de Medicina Veterinária, 1981;4:30-31.

6 - Linhares GFC, Filho FCD, Fernandes PR, Duarte SC. Tripanossomíase em bovinos no município de Formoso do Araguaia, Tocantins: relato de caso. Ciência Animal Brasileira, 2006;7:455-460.

7 - Batista JS, Riet-correa F, Teixeira MMG, Madruga CR, Simões SDV, Maia TF. Trypanosomiasis by Trypanosoma vivax in cattle in the Brazilian semiarid: Description of an outbreak and lesions in the nervous system. Veterinary Parasitology, 2007;143:174-181.

8 - Guerra NR, Monteiro MFM, Sandes HMM, Cruz NLN, Ramos CAN, Santana VLA, Souza MMA, Alves LC. Detecção de anticorpos IgG anti-Trypanosoma vivax em bovinos através do teste de imunofluorescência indireta. Pesquisa Veterinária Brasileira, 2013;33:1423-1426.

9 - Silva RAMS, Silva JA, Schneider RC, Freitas J, Mesquita D, Mesquita T, Ramirez L, Dávila AMR, Pereira MEB. Outbreak of trypanosomiasis due to Trypanosoma vivax (Ziemann, 1905) in bovine of the Pantanal, Brazil. Memórias do Instituto Oswaldo Cruz, 1996;52:561-562.

10 - Osório ALAR, Madruga CR, Desquenes M, Soares CO, Ribeiro LRR, da Costa CG. Trypanosoma (Dutonella) vivax: its biology, epidemiology, pathogenesis, and introduction in the New World: a review. Memórias do Instituto Oswaldo Cruz, 2008;103:1-13.

11 - Carvalho AU, Abrão DC, Facury filho EJ, Paes PRO, Ribeiro MFB. Ocorrência de Trypanosoma vivax no estado de Minas Gerais. Arquivo Brasileiro de Medicina Veterinária e Zootecnia, 2008;60:769-771.

12 - Cadioli FA, Barnabé PA, Machado RZ, Teixeira MCA, André MR, Sampaio PH, Fidélis junior OL, Teixeira MMG, Marques LC. First report of Trypanosoma vivax outbreak in dairy cattle in São Paulo state, Brazil. Revista Brasileira de Parasitologia Veterinária, 2012, v. 21, p. 118-124.

13 - Silva AS, Costa MM, Polenz MF, Polenz CH, Teixeira MMG, Lopes STA, Monteiro SG. Primeiro registro de Trypanosoma vivax em bovinos no Estado do Rio Grande do Sul, Brasil. Ciência Rural, 2009;39:2550-2554.

14 - Batista JS, Bezerra FSB, Lira RA, Carvalho JRG, Rosado neto AM, Petri AA, Teixeira MMG. Aspectos clínicos, epidemiológicos e patológicos da infecção natural em bovinos por Trypanosoma vivax na Paraíba. Pesquisa Veterinária Brasileira, 2008;28:63-69.

15 - Cuglovici DA, Bartholomeu DC, Reis-cunha JL, Carvalho AU, Ribeiro MFB. Epidemiologic aspects of an outbreak of Trypanosoma vivax in a dairy cattle herd in Minas Gerais state, Brazil. Veterinary Parasitology, 2010:169:320-326.

16 - Frange, R.C.C. Tripanossomíase em vacas na microrregião de Uberaba - MG: estudo soroepidemiológico e relato de surto. 2013. [dissertation] [In portuguese] (Mestrado em Sanidade e Produção Animal nos Trópicos) - Universidade de Uberaba, Uberaba - MG. Disponível em http:/www.bibliotecadigital.ufmg.br/dspace/ bitstream/handle/1843/SMOC-AAQNS4/rodrigo melo meneses.pdf?sequence=1, acesso em agosto 2016.

17 - Guglielmone AA. Epidemiology of babesiosis and anaplasmosis in South and Central America. Veterinary Parasitology, 1995;57:109-119.

18 - Grisi L, Massard CL, Moya-borja GE, Pereira JB. Impacto econômico das principais ectoparasitoses em bovinos no Brasil. A Hora Veterinária, 2002;21(125):8-10.

19 - Araújo FR, Madruga CR, Leal CRB, Bastos PAS, Marques APC. Freqüência de anticorpos antiAnaplasma marginale em rebanhos leiteiros da Bahia. Arquivo Brasileiro de Medicina Veterinária e Zootecnia, 1998;50(3):243-6. 
20 - Dalagnol CA, Martins E, Madruga CR. Prevalência de anticorpos contra Babesia bovis, Babesia bigemina, Anaplasma marginale em bovinos de corte na região de clima $\mathrm{Cfb}$. Revista Brasileira de Parasitologia Veterinária, 1995;4:220, Suplemento 1.

21 - IBGE - Instituto Brasileiro de Geografia e Estatística. Censo agropecuário 2006, produção de leite, available at: $<$ http://sidra.ibge.gov.br/bda/tabela/listabl.asp. $>$ accessed 3 feb. 2012.

22 - Jordan D, Mcewen SA. HerdAcc: herd-level test performance based on uncertain estimates of individual test performance, individual true prevalence and herd true prevalence, Preventive Veterinary Medicine, 1998;3:187-209.

23 - Ashkar, T., Ochilo, M. The application of the indirect fluorescent antibody test to samples of dried sera and blood from cattle in the Lambwe Valley, South Nyanza, Kenya. Bull. World Health Organ. 1972;47: 769-772.

24 - Platt, K. B., Adams, L. G. Evaluation of indirect fluorescent antibody test for detecting Trypanosoma vivax in South American cattle. Research in Veterinary Science. 1976;21:53 - 58.

25 - Ogunremi O, Halbert G, Mainar-jaime R, Benjamin J, Pfister K, Lopez-rebollar L, Georgiadis MP. Accuracy of an indirect fluorescent-antibody test and of a complement-fixation test for the diagnosis of Babesia caballi in field samples from horses. Preventive Veterinary Medicine, 2008;83:41-51.

26 - Ekici OD and Sevinc F. Comparison of cELISA and IFA tests in the serodiagnosis of anaplasmosis in cattle. African Journal of Microbiology Research, 2011;5(10):1188-1191.

27 - Noordhuizen JPTM, Frankena K, Thrusfield MV, Graat EAM. Application of quantitative methods in veterinary epidemiology. Wageningen Pers Publication, Wageningen, 2001, 429p.

28 - Sergeant ESG. Epitools epidemiological calculators. Australian Veterinary Animal Health Services and Australian Biosecurity Cooperative Research Centre for Emerging Infectious Disease, 2009, available at: http://epitools.ausvet.com.au, accessed 25 Jan 2014.

29 - Reiczigel J, Földi J, Ózsvári L. Exact confidence limits for prevalence of a disease with an imperfect diagnostic test. Epidemiology and Infection, 2010;138:1674-1678.

30 - Bruhn FRP, Daher DO, Lopes E, Barbieri JM, Rocha CMBM, Guimarães AM. Factors associated with seroprevalence of Neospora caninum in dairy cattle in southeastern Brazil. Tropical Animal Health Production, 2013;45:1093-1098.

31 - Organización Panamericana de la Salud (OPS). Organización Mundial de la Salud (OMS). 1973. Procedimientos para Estudios de Prevalencia de Enfermedades Crónicas en el Ganado. Centro Panamericano de Zoonosis. Nota Técnica $N^{\circ} 18$. Buenos aires, Argentina. 35 p.

32 - FAEMG. Diagnóstico da pecuária leiteira do estado de Minas Gerais em 2005: Relatório de Pesquisa. Belo Horizonte: FAEMG, 2006. 156p.

33 - INSTITUTO INTERAMERICANO DE COOPERACION PARA LA AGRICULTURA - IICA. Técnicas para el diagnostico de babesiosis y anaplasmosis bovinas. San José, Costa Rica, 1987. 79p available at: http:// repiica.iica.int/docs/B1335e/B1335e.pdf. Accessed 11 apr 2014.

34 - Carvalho AHO, Silva júnior FA, Daher DO, Rocha CMBM, Guimarães AM. Efeito do sistema de produção de leite sobre a estabilidade enzoótica para Anaplasma marginale e Babesia bovis em bezerras na região do Campo das Vertentes de Minas Gerais, Brasil. Semina: Ciências Agrárias, 2012;33:323-332.

35 - Corbellini LG, Smith DR, Pescador CA, Schmitz M, Correa A, Steffen DJ, Driemeier D. Herd-level risk factors for $N$. caninum seroprevalence in dairy farms in southern Brazil, Preventive Veterinary Medicine, 2008;74:130-141. 
36 - Hanley JA, Negassa A, Edwardes MDB, Forrester JE. Statistical Analysis of Correlated Data Using Generalized Estimating Equations: An Orientation, American Journal Epidemiology, 2003;157:364-375.

37 - Mahoney DF, Ross DR. Epizootiological factors in the control of bovine babesioses. Australian Veterinary Journal, 1972;48(5):292-298.

38 - Pereira MA, Guimarães AM, Rocha CMBM. Efeito da estação de nascimento sobre a frequência de bezerras soropositivas para Anaplasma marginale e Babesia bovis na região Sul de Minas Gerais, Brasil. Ciência Animal Brasileira, 2009;10(3):975-983.

39 - Madruga CR, Araújo FR, Cavalcante-goes G, Martins C, Pfeifer IB, Ribeiro LR, Kessler RH, Soares CO, Miguita M, Melo EPS, Almeida RFC, Lima jr MMSC. The development of an enzyme-linked immunosorbent assay for Trypanosoma vivax antibodies and its use in epidemiological surveys. Memórias Instituto Oswaldo Cruz, 2006;101:801-807.

40 - Guedes Junior DS, Araújo FR, Silva FJM, Rangel CP, Barbosa neto JD, Fonseca AH. Frequency of antibodies to Babesia bigemina, B. bovis, Anaplasma marginale, Trypanosoma vivax and Borrelia burgdorferi in cattle from the Northeastern region of the State of Pará, Brazil. Revista Brasileira de Parasitologia Veterinária, 2008;17:105-109.

41 - Batista JS, Oliveira AF, Rodrigues CMF, Damasceno CAR, Oliveira IRS, Alves HM, Paiva ES, Brito PD, Medeiros JMF, Rodrigues AC, Teixeira MMG. Infection by Trypanosoma vivax in goats and sheep in the Brazilian semiarid region: From acute disease outbreak to chronic cryptic infection. Veterinary Parasitology, 2009; 165:131-135.

42 - Kocan KM, De la fuente J, Blouin EF, Coetzee JF, Ewing SA. The natural history of Anaplasma marginale. Veterinary Parasitology, 2010;167:95-107. 